\section{BRAZIULIAN JOURNAL}

OF MEDICAL AND BIOLOGICAL RESHARCH

www.bjournal.com.br
ISSN 0100-879X

Volume 43 (11) 1010-1134 November 2010

BIOMEDICAL SCIENCES

AND

CLINICAL INVESTIGATION

Braz J Med Biol Res, November 2010, Volume 43(11) 1034-1041

doi: 10.1590/S0100-879X2010007500106

Effect of hyperoxia on the intestinal IgA secretory component in neonatal rats and on intestinal epithelial cells in vitro

D.Y. Liu and J.J. Li

The Brazilian Journal of Medical and Biological Research is partially financed by
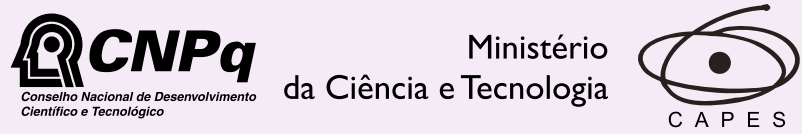

Ministério da Educação

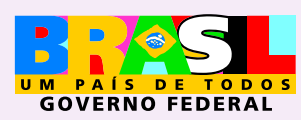

DFAPESP

Institutional Sponsors
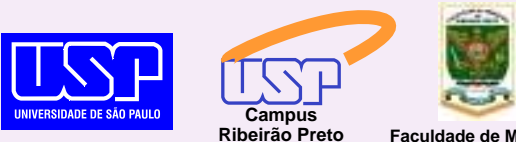

Ф SHIMADZU

GE Healthcare
Hotsite of proteomics metabolomics developped by: 


\title{
Effect of hyperoxia on the intestinal IgA secretory component in neonatal rats and on intestinal epithelial cells in vitro
}

\author{
D.Y. Liu ${ }^{1}$ and J.J. Li²
}

${ }^{1}$ Research Centre, ${ }^{2}$ Pediatry Department, China Medical University Affiliated Shengjing Hospital, Shenyang City, Liaoning Province, China

\begin{abstract}
Oxygen therapy is essential for the treatment of some neonatal critical care conditions but its extrapulmonary effects have not been adequately investigated. We therefore studied the effects of various oxygen concentrations on intestinal epithelial cell function. In order to assess the effects of hyperoxia on the intestinal immunological barrier, we studied two physiological changes in neonatal rats exposed to hyperoxia: the change in intestinal IgA secretory component (SC, an important component of SlgA) and changes in intestinal epithelial cells. Immunohistochemistry and Western blot were used to detect changes in the intestinal tissue SC of neonatal rats. To detect intestinal epithelial cell growth, cells were counted, and 3-(4,5-dimethylthiazol-2-yl)-2,5diphenyltetrazolium bromide (MTT) and Giemsa staining were used to assess cell survival. Immunohistochemistry was used to determine SC expression. The expression of intestinal SC in neonatal rats under hyperoxic conditions was notably increased compared with rats inhaling room air $(\mathrm{P}<0.01)$. In vitro, $40 \% \mathrm{O}_{2}$ was beneficial for cell growth. However, $60 \% \mathrm{O}_{2}$ and $90 \%$ $\mathrm{O}_{2}$ induced rapid cell death. Also, $40 \% \mathrm{O}_{2}$ induced expression of SC by intestinal epithelial cells, whereas $60 \% \mathrm{O}_{2}$ did not; however, $90 \% \mathrm{O}_{2}$ limited the ability of intestinal epithelial cells to express SC. In vivo and in vitro, moderate hyperoxia brought about increases in intestinal SC. This would be expected to bring about an increase in intestinal SlgA. High levels of SC and SlgA would serve to benefit hyperoxia-exposed individuals by helping to maintain optimal conditions in the intestinal tract.
\end{abstract}

Key words: Intestinal epithelial cells; Cell growth; Secretory component; Hyperoxia; Secretory IgA

\section{Introduction}

Oxygen therapy (continuously inhaling a high concentration of oxygen, resulting in hyperoxia) is essential for the treatment of some neonatal critical care conditions, but its extrapulmonary effects have not been adequately investigated. We, therefore, studied the effects of various oxygen concentrations on intestinal epithelial cell functions. The lungs are the primary targets of hyperoxia. Pathophysiological manifestations of pulmonary oxygen toxicity have been extensively studied in neonatal rats (1), such as hyperoxia-induced pulmonary injury, retinopathy $(2,3)$ and neurological disorders (4). There have been some reports about the effect of hyperoxia on intestinal epithelial cells in vitro (5-7). In vivo, hyperoxia creates intestinal serosal and submucosal vasodilation, vascularization, and growth retardation in neonatal rats (8). Because the intestinal villi and mucosa continue to grow and differentiate after birth, the long-term effects of postnatal hyperoxia exposure may be most relevant to the human infant (9).

Secretory $\lg A$ (SIgA) plays a critical role as an immunological barrier in the intestine. It is the predominant intestinal immunoglobulin, and acts as the first line of defense for the intestinal mucosa. SIgA adheres mainly to bacteria or viruses on the intestinal epithelial surface. It guarantees both immune exclusion and neutralization of translocated bacteria, thus preserving the integrity of the intestinal barrier by preventing bacterial-induced inflammation. The anti-inflammatory properties of SIgA are well-known (1012). SIgA secreted into the intestinal mucus is an important regulatory factor for maintaining the intestinal barrier (13). Also, SIgA may weaken bacterial translation (14-16). The secretory component (SC) in association with polymeric $\lg \mathrm{A}(\mathrm{plg} \mathrm{A})$ forms SIgA. The SC is secreted by intestinal epithelial cells and is responsible for the transcytosis of newly synthesized plgA and the formation of SIgA (17).

Correspondence: D.Y. Liu, Research Center, China Medical University Affiliate Shengjing Hospital, No. 36, Sanhao Street, Heping District, Shenyang City, Liaoning Province, China. E-mail: dongyan.liu@yahoo.com.cn

Received June 9, 2010. Accepted September 28, 2010. Available online October 8, 2010. Published November 12, 2010. 
$\mathrm{SC}$ is the extracellular component of the poly lg receptor (plgR), which is expressed on the intestinal epithelial surface. SC prevents proteolytic degradation of SIgA, and also increases the viscosity of the mucus enough to allow mucosal adhesion and mucosal immunological defense. $\mathrm{SC}$ is a nonspecific scavenger of microorganisms and plays a key role in the protection of the intestinal mucous membrane, and also in limiting the inflammation process there (18). SC is important for defense against bacteria (19-22) and parasites (23). Moreover, SC can play a critical role in the immunologically mediated neutralization of cholera toxin (24). We have found that ileal SIgA was remarkably increased in neonatal rats under conditions of hyperoxia (25). In the present study, neonatal rats inhaled continuously high concentrations of oxygen (hyperoxia) for 14 and 21 days. We then assayed for changes in the expression of intestinal SC induced by the hyperoxia. We used cell counting, along with 3-(4,5-dimethylthiazol-2yl)-2,5-diphenyltetrazolium bromide (MTT) and Giemsa staining, to detect the growth, cell division, and survival of intestinal epithelial cells treated with hyperoxia, and immunohistochemistry to detect SC expression in intestinal epithelial cells treated with hyperoxia. Our aim was to gain a better understanding of the effects of hyperoxia on the immunological barrier of the gut.

\section{Material and Methods}

\section{Animal model}

Wistar rats were obtained from the China Medical University (Shenyang, China). The study was approved by the animal Ethics Committee of China Medical University. Timed pregnant Wistar rats were transported to our laboratory one week before delivery and were individually housed in transparent cages. Room temperature, humidity, and daily light-dark cycles were automatically controlled. All pregnant rats delivered within a 12-h period and their pups were randomly divided into an airinhaling group (exposed to room air, $\mathrm{N}=20$ ) and hyperoxia group $\left(90-95 \% \mathrm{O}_{2}, \mathrm{~N}=40\right)$. All pups were individually weighed and numbered on the back with a permanent ink marker and then placed in environmentally controlled chambers. In the hyperoxia group, oxygen was continuously delivered into sealed environmental chambers to achieve a constant concentration of 90-95\% oxygen, as confirmed by an oxygen monitor (OM-25ME, MAXTEC, USA) daily. The air-inhaling group was exposed to similar environmental conditions, except for inhaling room air. Oxygen and room air were filtered through natrolite to keep the $\mathrm{CO}_{2}$ concentration below $0.5 \%$ (as confirmed using a DapexGas Monitor, USA). To equalize the effect of nursing on the pups' development, at $24 \mathrm{~h}$ the mothers were cross-fostered to the opposite litter (the air-inhaling group to the hyperoxia group and vice versa). The dams were switched every $24 \mathrm{~h}$ throughout the protocol. Each pup was weighed daily. Pups were sacrificed on the 14th and 21st day and their intestinal tissues were dissected.

\section{Immunohistochemistry for the detection of intestinal tissue SC}

Paraffin-embedded sections of the intestinal tissues of rats were deparaffinized, rehydrated, and incubated with rabbit anti-rat SC (Bethyl, USA). The slides were rinsed three times with PBS between incubations, and sections were counterstained with hematoxylin. The primary antibody was replaced with PBS as a negative control. The median absorbance value of SC was determined with the Image analysis software (Shanghai, China) after scanning.

\section{Western blot analysis of SC protein of intestinal tissues}

Proteins extracted from intestinal tissues were separated by sodium dodecyl sulfate (SDS) polyacrylamide gel electrophoresis and transferred to polyvinylidene fluoride membranes. The membranes were blocked with Tris-buffer containing $50 \mathrm{ng} / \mathrm{L}$ skim milk and probed with rabbit anti-rat SC antibody (Bethyl) or $\beta$-actin (Sigma, USA) followed by a peroxidase-conjugated secondary antibody. They were then incubated with an enhanced chemiluminescent substrate and exposed to X-OMAT film (Perkin Elmer, USA). Images were scanned and analyzed with the Tanon GIS-2020 software (Tanon, China).

\section{Cell culture}

The Caco-2 cell line was obtained from the Cell Biology Institute of Shanghai, China. Caco-2 cells were cultured on two $5-\mathrm{mm}$ plastic Petri dishes at $37^{\circ} \mathrm{C}$ in air and $5 \% \mathrm{CO}_{2}$ in 1640 medium (Gibco, Invitrogen Co., USA), supplemented with $20 \%$ fetal calf serum (FCS), $100 \mu \mathrm{g} / \mathrm{mL}$ streptomycin and $100 \mathrm{IU} / \mathrm{mL}$ penicillin, $\mathrm{pH} 7.4$ (regulated with $3.7 \mathrm{~g} / \mathrm{L}$ $\mathrm{NaHCO}_{3}$ ). We selected the Caco-2 cell line because the Caco-2 cell monolayer is a model of intestinal epithelial cells, with the same enzymes, transporters, and morphology as intact human intestinal epithelial cells, with remarkable morphological and biochemical similarity to the columnar epithelium of the small intestine (26).

\section{Growth curve constructed by counting cells}

Prior to counting, cells were plated with fresh medium and cultured at $37^{\circ} \mathrm{C}$ in air and $5 \% \mathrm{CO}_{2}$ for $24 \mathrm{~h}$. On the 2 nd day after plating, all nonadherent cells were discarded and the remaining cells were equally divided into groups and gassed with $5 \% \mathrm{CO}_{2}: 40 \% \mathrm{O}_{2}, 5 \% \mathrm{CO}_{2}: 60 \% \mathrm{O}_{2}$, or $5 \% \mathrm{CO}_{2}: 90 \% \mathrm{O}_{2}$. Then, cells were counted on the 1st, 2nd, 3rd, 4th, 5th, and 6 th days. Each sample was tested six times.

\section{MTT}

Prior to treatment, cells were plated onto 96-well microtiter plates with fresh medium and cultured at $37^{\circ} \mathrm{C}$ in air and $5 \%$ $\mathrm{CO}_{2}$ for $24 \mathrm{~h}$. On the $2 \mathrm{nd}$ day after plating, all nonadherent cells were discarded and the remaining cells were equally divided into groups gassed with $5 \% \mathrm{CO}_{2}: 40 \% \mathrm{O}_{2}, 5 \% \mathrm{CO}_{2}: 60 \% \mathrm{O}_{2}$, or $5 \% \mathrm{CO}_{2}: 90 \% \mathrm{O}_{2}$. Then, on the 3rd and 6th days, cells were 
treated with $20 \mu \mathrm{L}$ MTT for $4 \mathrm{~h}$ at $37^{\circ} \mathrm{C}$. The reactions were stopped by adding DMSO. The absorbance of each well was determined at $450 \mathrm{~nm}$. Each sample was tested six times.

\section{Cell division experiment}

Caco- 2 cells were cultured on coverslips at $37^{\circ} \mathrm{C}$ in air and $5 \% \mathrm{CO}_{2}$ for $24 \mathrm{~h}$. On the 2 nd day, cells on coverslips were divided equally into groups gassed with $5 \% \mathrm{CO}_{2}: 40 \% \mathrm{O}_{2}$, $5 \% \mathrm{CO}_{2}: 60 \% \mathrm{O}_{2}$, or $5 \% \mathrm{CO}_{2}: 90 \% \mathrm{O}_{2}$. Then, on the 3rd and 6th days, cells were fixed on coverslips with methanol/glacial acetic acid (3:1) for 30 min and counterstained with Giemsa for $10 \mathrm{~min}$. Mitotic cells were counted. The mitotic index was calculated as mitotic cells/total cell number. Each sample was tested six times.

\section{Immunohistochemistry for the detection of SC expression by Caco- 2 cells}

Cells on coverslips were fixed with $4 \%$ paraformaldehyde and incubated with $3 \% \mathrm{H}_{2} \mathrm{O}_{2}$. Then, sections were treated with $10 \%$ goat serum for 30 min and incubated with goat anti-rat SC (Bethyl) overnight at $4^{\circ} \mathrm{C}$. The sections were counterstained with hematoxylin. The primary antibody was replaced with PBS as a negative control.

\section{Statistical analysis}

Data are reported as means \pm SD. Statistical differences between treatment groups were determined by the $t$-test. Growth curves were calculated as the best fit for exponential curves, and ANOVA with Bonferroni's correction was used for coupled categories.

\section{Results}

\section{Mortality rate and growth rate of neonatal rats exposed to hyperoxia}

Weight loss was observed in neonatal rats after 7-10 days of hyperoxia exposure. The body weight of neonatal rats in the

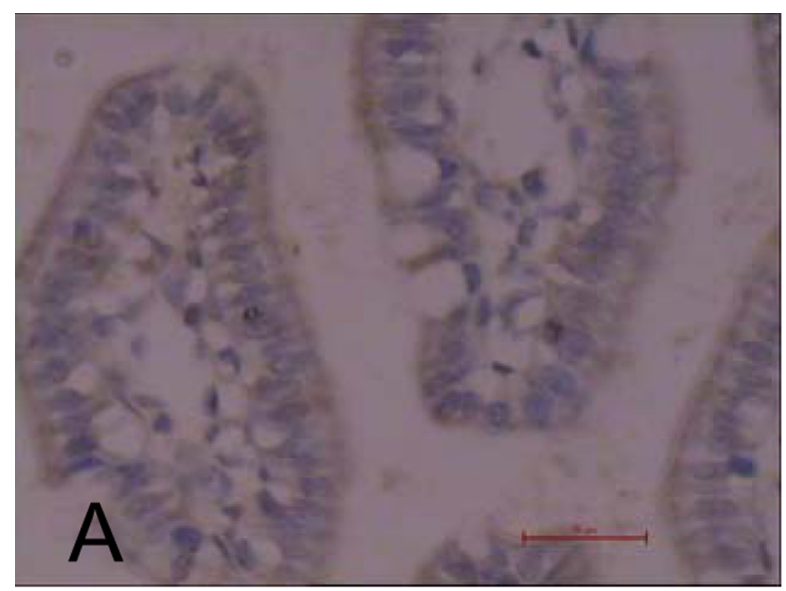

hyperoxia group was lower than that of the air-inhaling group (Figure 1). The mortality of the neonatal rats in the hyperoxia group was $45.9 \pm 4.2 \%$ at day 14 and $62.5 \pm 4.2 \%$ at day 21 . Weight gain and mortality of the air-inhaling group of neonatal rats were normal.

\section{SC was enhanced in ileal tissue of neonatal rats exposed to hyperoxia}

The expression of SC in the cytoplasm and on the membranes of intestinal epithelial cells was remarkably enhanced in the hyperoxia group compared to the air-inhaling group (Figure 2). In the hyperoxia group, the median absorbance values for SC were $6.5 \pm 1.2$ at day 14 and $7.0 \pm 1.5$ at day 21 . In the air-inhaling group, the median absorbance

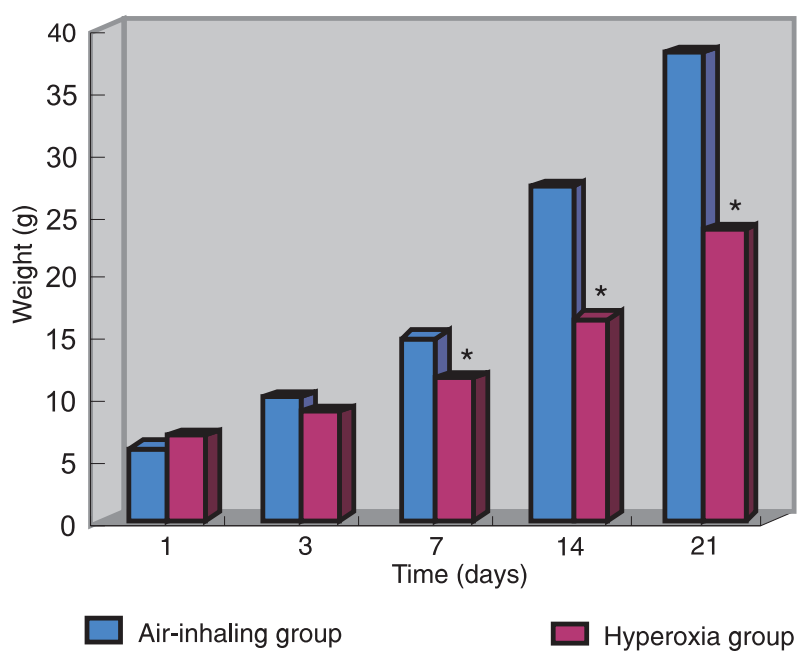

Figure 1. Weight of rats in the air-inhaling and hyperoxia groups. The body weight of the hyperoxia rats started to be lower than that of the air-inhaling rats on the 3rd day. From the 7th to the 21 st day, the body weight of the hyperoxia rats was significantly lower compared to that of the air-inhaling group $\left({ }^{*} \mathrm{P}<0.01, t\right.$-test $)$.

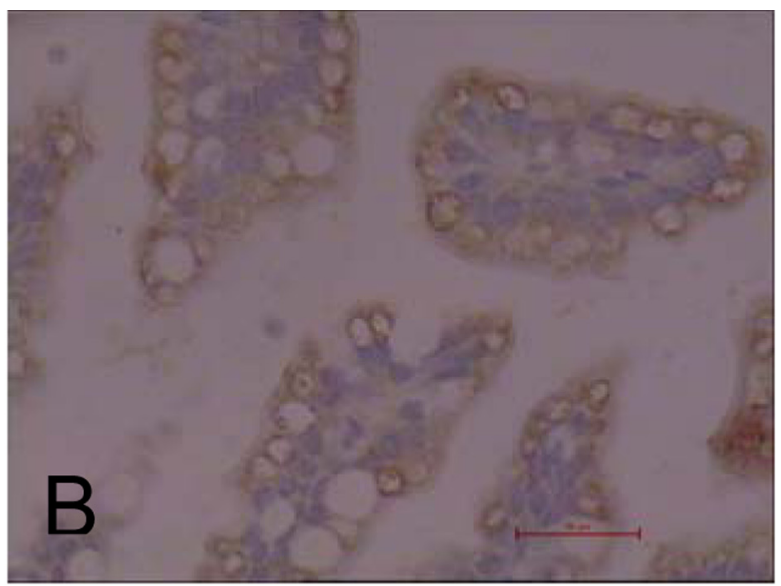

Figure 2. Staining of the secretory component (SC) in intestinal epithelial cells (40X). A, The SC of intestinal epithelial cells stained pale brown in the air-inhaling group and deep brown in the hyperoxia group $(B)$. 
values for SC were $3.1 \pm 1.1$ at day 14 and $3.2 \pm 1.3$ at day 21 . Also, the median absorbance value for SC in the hyperoxia group was notably increased compared with the air-inhaling group $(P<0.01$; Figure 3$)$.

\section{SC protein was increased in ileal tissue of neonatal rats exposed to hyperoxia}

SC protein expression was increased in the hyperoxia group relative to the air-inhaling group. In the hyperoxia group, the relative expression rate of SC (absorbance value of SC/absorbance value of $\beta$-actin) was $0.919 \pm 0.060$ at day 14 and $0.934 \pm 0.044$ at day 21 . In the air-inhaling group, the relative expression rate of SC (absorbance value of SC/absorbance value of $\beta$-actin) was $0.702 \pm 0.032$ at day 14 and $0.704 \pm 0.022$ at day 21 . The relative expression rate of SC was notably increased in the hyperoxia group compared to the air-inhaling group at days 14 and 21 ( $P<0.01$; Figure 4).

\section{Effect of hyperoxia on Caco-2 cell growth}

The growth of Caco- 2 cells was significantly affected by 60 and $90 \% \mathrm{O}_{2}$, as shown in Figure 5 . Growth in $40 \% \mathrm{O}_{2}$ was increased at day 2 and was exponentially increased at days 4 and 5 . When the gas was changed to $60 \% \mathrm{O}_{2}$, the growth rate decreased. Cells in $90 \% \mathrm{O}_{2}$ had arrested growth followed by rapid death. Significant differences in cell numbers were found between $21 \% \mathrm{O}_{2}$ and both 60 and $90 \% \mathrm{O}_{2}(\mathrm{P}<0.001)$. Significant differences in cell numbers were also found between $40 \% \mathrm{O}_{2}$ and both 60 and $90 \% \mathrm{O}_{2}(\mathrm{P}<0.001)$. There was also a significant difference in cell numbers for 60 and $90 \% \mathrm{O}_{2}$ $(P<0.001)$. These results suggest that cells can adapt to $40 \% \mathrm{O}_{2}$, but 60 and $90 \% \mathrm{O}_{2}$ cause severe cell damage and eventually cell death.

\section{Effect of hyperoxia on Caco-2 cell survival}

MTT was used to detect cell survival. At day 3 , cells that were cultured at 40 and $60 \% \mathrm{O}_{2}$ were unchanged in population, but at $90 \% \mathrm{O}_{2}$, cells underwent rapid death $(P<0.01)$. At day 6 , cells that were cultured at $40 \% \mathrm{O}_{2}$ increased in number $(\mathrm{P}>0.01)$, but at 60 and $90 \% \mathrm{O}_{2}$ their numbers were rapidly decreased compared to cells cultured at $21 \% \mathrm{O}_{2}(\mathrm{P}<0.01$; as shown in Figure 6$)$. This showed that moderate oxygen induced intestinal epithelial cell growth.

\section{Effect of hyperoxia on Caco-2 cell division}

At day 3 , the mitotic indices of cells grown in 40,60 and $90 \% \mathrm{O}_{2}$ were significantly decreased compared to those grown in $21 \% \mathrm{O}_{2}$. However, at day 6 , the mitotic index of cells grown in $40 \% \mathrm{O}_{2}$ was increased compared with those grown in $21 \% \mathrm{O}_{2}$. At $60 \% \mathrm{O}_{2}$, the mitotic index was decreased, and some cell nuclei were larger than those seen under the $21 \% \mathrm{O}_{2}$ conditions. At day 6 , cell splitting was not observed at $90 \% \mathrm{O}_{2}$ and the nuclei of living cells

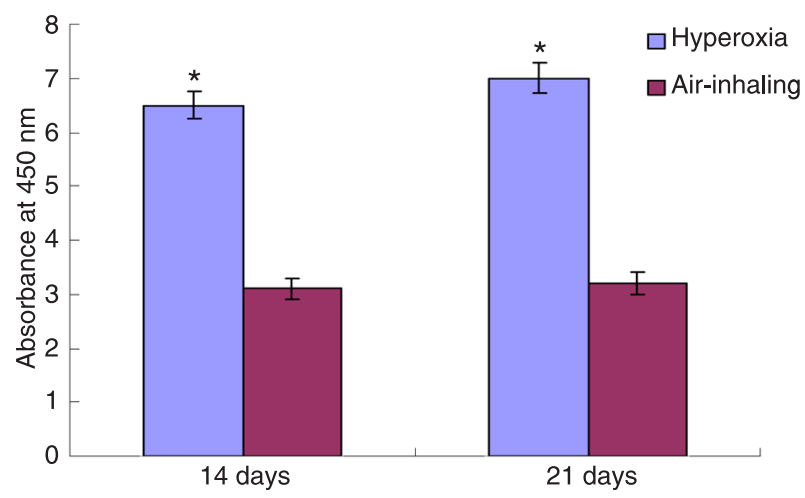

Figure 3. Absorbance of the intestinal secretory component (SC) in the hyperoxia and air-inhaling groups. The mean absorbance value of SC was notably increased in the hyperoxia group compared to the air-inhaling group ( ${ }^{*} \mathrm{P}<0.01, t$-test).
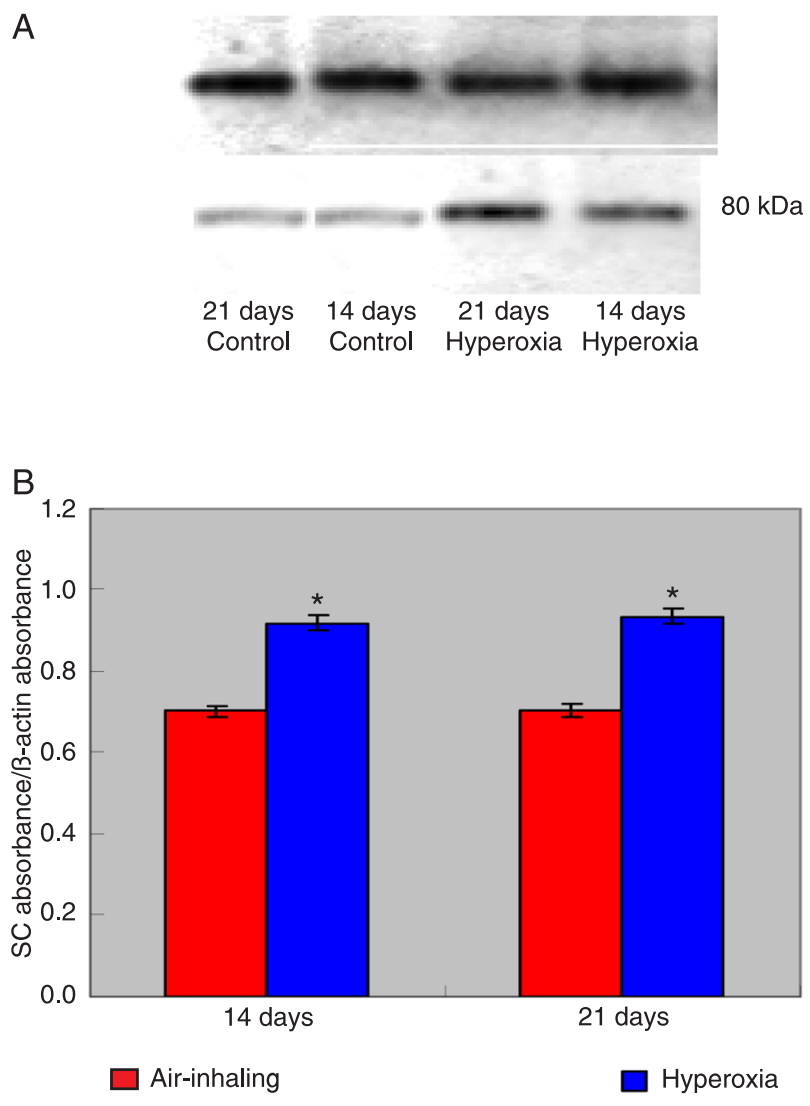

Figure 4. The intestinal secretory component (SC) protein of rats was notably increased in the hyperoxia group. $A, \mathrm{SC}$ protein was detected by Western blot. $B$, Densitometric analysis using image software. Absorbance value of SC/absorbance value of $\beta$-actin was notably increased in the hyperoxia group compared to the air-inhaling group ( ${ }^{*} \mathrm{P}<0.01, t$-test). 
were larger than those seen under $21 \% \mathrm{O}_{2}$ conditions (as shown in Figure 7).

\section{Immunochemical analysis of the effects of hyperoxia on SC-positive cells \\ $\mathrm{SC}$ is mainly localized in the cytoplasm and cell mem-}

branes of Caco-2 cells, as shown in Figure 8. SC-positive cells constituted about $0.1-0.5 \%$ of the population of cells grown in $21 \% \mathrm{O}_{2}$ and about $0.4-0.8 \%$ of the population of cells grown in $40 \% \mathrm{O}_{2}$. SC-positive cells constituted about $0.2-0.7 \%$ of the population of cells grown in $60 \%$ $\mathrm{O}_{2}$. The expression of $\mathrm{SC}$ in Caco- 2 cells was remarkably

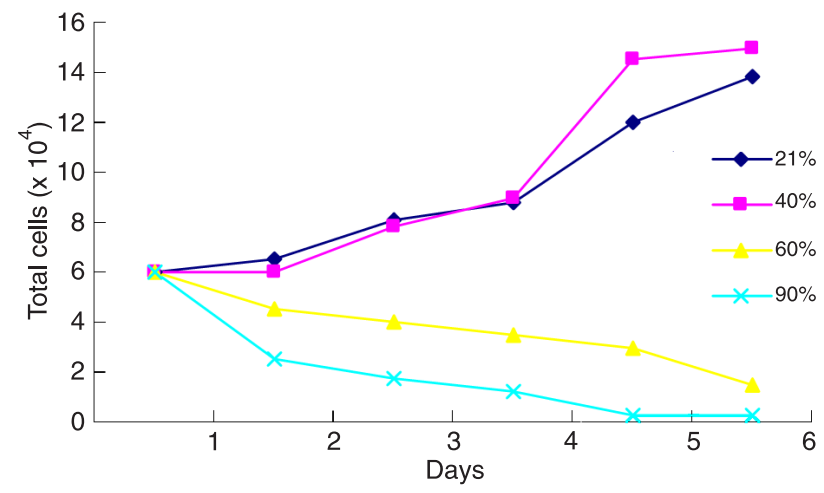

Figure 5. Influence of $\mathrm{O}_{2}$ concentration on Caco-2 cell growth. Each data point represents the mean cell number of 5-6 plastic Petri dishes from each of six preparations of mixed Caco-2 cells. Cells were maintained in $21,40,60$, and $90 \% \mathrm{O}_{2}$.

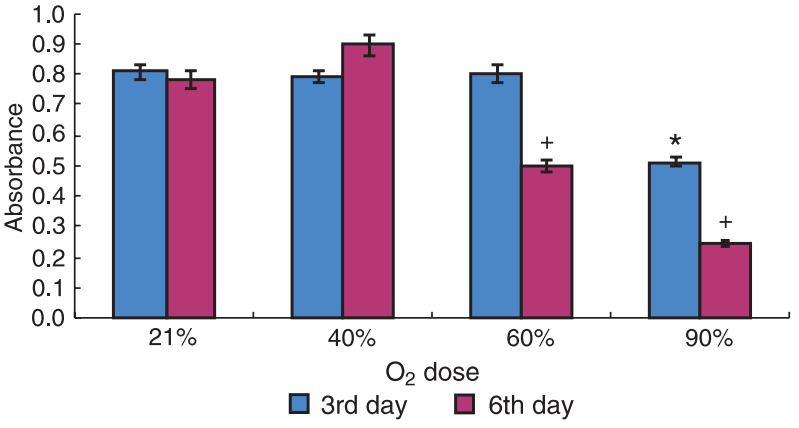

Figure 6. Effect of hyperoxia on Caco-2 cell survival. On the 3rd day, cells rapidly died in the presence of $90 \% \mathrm{O}_{2}\left({ }^{*} \mathrm{P}<0.01, t-\right.$ test) and on the 6th day, at 60 and $90 \% \mathrm{O}_{2}$ cell numbers were rapid decreased compared to $21 \% \mathrm{O}_{2}\left({ }^{+} \mathrm{P}<0.01\right.$, $t$-test). At $40 \%$ $\mathrm{O}_{2}$, cell growth was good.
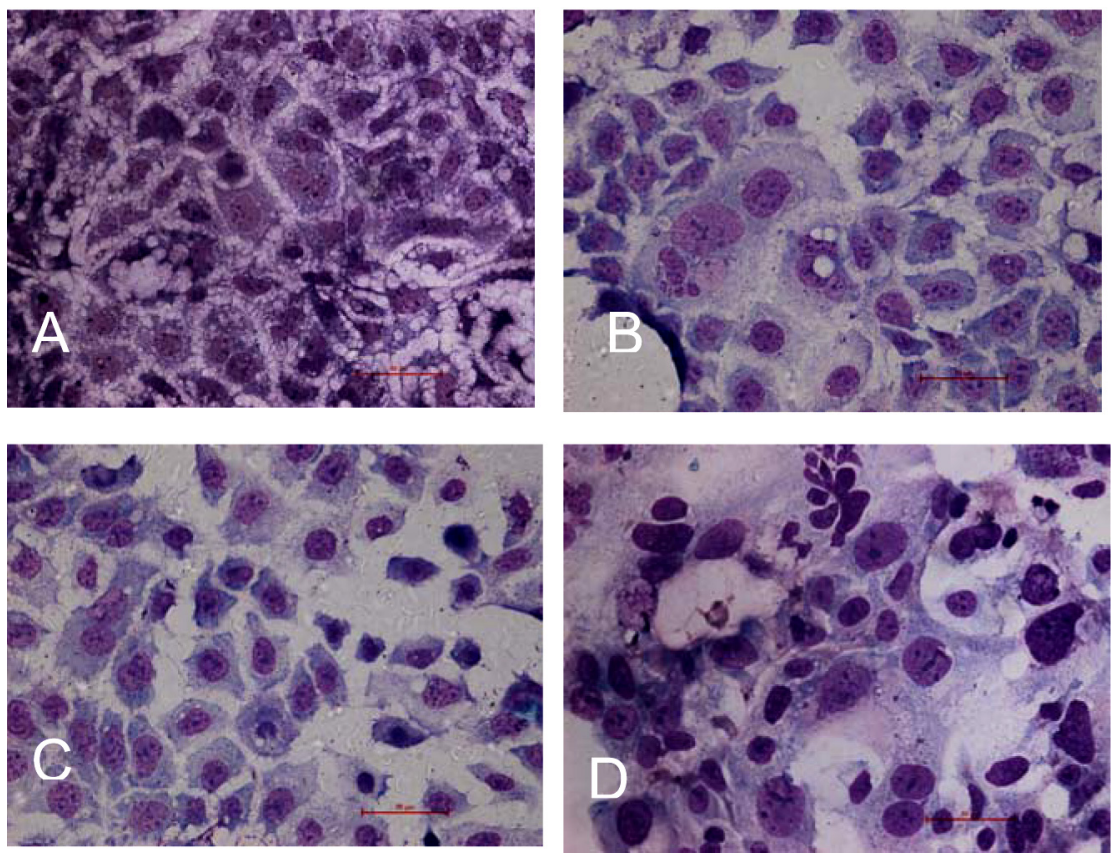

Figure 7. Effect of hyperoxia on Caco-2 cell division (40X). A, $21 \% \mathrm{O}_{2}$ : cells distributed densely, some cells were splitting, and the mitotic index was $2.5 \% ; \mathrm{B}, 40 \% \mathrm{O}_{2}$ : compared to $21 \% \mathrm{O}_{2}$, cell splitting was increased and the mitotic index was $3.3 \% ; \mathrm{C}, 60 \% \mathrm{O}_{2}$ : compared to $21 \% \mathrm{O}_{2}$, cell splitting was decreased, the mitotic index was $1.3 \%$ and many larger cell nuclei were observed; $D, 90 \% \mathrm{O}_{2}$ : cell splitting was not observed and only larger cell nuclei were seen. 

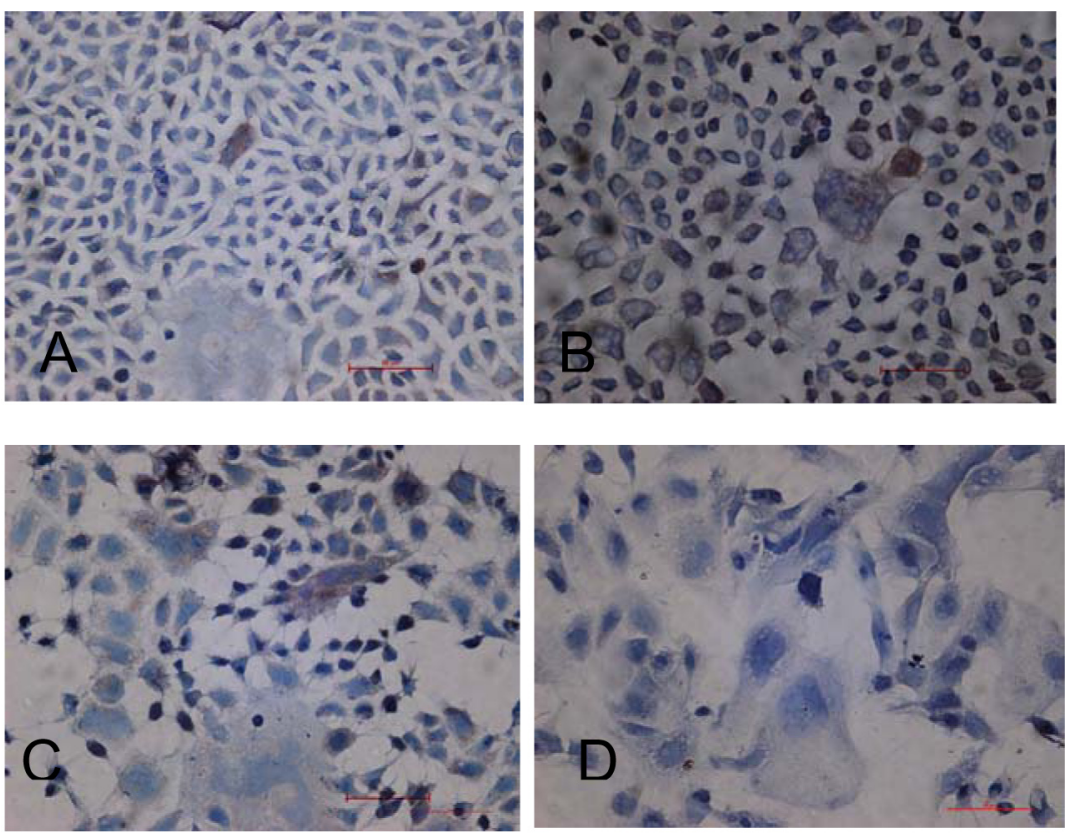

Figure 8. Effect of hyperoxia on the intestinal secretory component (SC) expression of Caco-2 cell (40X). A, The expression of SC in the cytoplasm and on the membranes of Caco-2 cell was pale brown. $B$, The expression of SC in the cytoplasm and on the membranes of Caco-2 cell was deep brown. $C$, The expression of SC in the cytoplasm and on the membranes of Caco-2 cell was brown. $D$, The expression of SC of Caco-2 cell was remarkably decreased. SC-positive cell was not seen in $90 \% \mathrm{O}_{2}$.

decreased as the percentage of oxygen was increased above $60 \%$, and SC-positive cells were not demonstrable in cells grown in $90 \% \mathrm{O}_{2}$.

\section{Discussion}

The intestinal tract faces physiological challenges in the human body. It must provide ready access to ingested nutrients and also protect against food-borne microbes. This challenge is met by multiple specific and nonspecific host defenses that establish and maintain a selective intestinal barrier. This immunological intestinal barrier is critical for defense against intestinal microbes and their toxins.

Oxygen therapy, leading to hyperoxia, is a necessary method for the treatment of some critical care conditions. The high concentration of oxygen inhaled, however, may be both a friend and a foe of the body. An adequate oxygen supply serves to maintain the physical integrity of the mucosa, thus decreasing invasion of the lumen by microbes. An adequate supply of oxygen is also important for effective bactericidal function of resident neutrophils and other phagocytic cells in the gut (7). However, hyperoxia also enhances the inflammatory response in adult mice infected with influenza A virus (27). It has been proposed that normobaric hyperoxia might affect certain peripheral organs (kidney, ileum) (8). The thickness of the ileal mucosa of neonatal rats under conditions leading to hyperoxia was significantly greater (9). Hyperoxia may affect the barrier function of the newborn rat's intestine, rendering it susceptible to bacterial insult (9). In this study, the expression of SC protein in neonatal rats under conditions leading to hyperoxia was increased compared to that of air-inhaling neonatal rats. The rise of SC may be due to the following causes: first, hyperoxia renders the intestinal mucosa of neonatal rats susceptible to bacterial insult. Bacterial invasion of the intestine stimulates intestinal epithelial cells to secrete more SC. Second, a direct effect of oxidative stress may induce changes in intestinal immunity cells, such as greater secretion of cytokines. Some cytokines regulate the expression of SC (28-30). Third, secondary systemic inflammation may be another cause of the rise of SC. These possibilities require further investigation. Increased SC expression is beneficial to the transcytosis of plgA and the formation of SIgA. This is favorable to the defense against oxygen toxicity from hyperoxia and bacterial insults. Then, SC and SIgA both exert immunological functions in the exclusion and neutralization of bacteria.

In order to better understand the influence of hyperoxia on intestinal epithelial cells, Caco-2 cells were treated in vitro with 40,60 and $90 \% \mathrm{O}_{2}$. Our results showed that Caco-2 cells rapidly grow at $40 \% \mathrm{O}_{2}$, but cell growth slows at $60 \%$ $\mathrm{O}_{2}$ and rapid death occurs at $90 \% \mathrm{O}_{2}$. At $40 \% \mathrm{O}_{2}$, the cell 
division rate reached $3.3 \%$. At $60 \% \mathrm{O}_{2}$, the cells continued to divide, although at a reduced rate. However, at $90 \% \mathrm{O}_{2}$, there was both growth arrest and cell death. This demonstrates that severe hyperoxia may check cell growth and kill intestinal epithelial cells, which in turn would facilitate the invasion of the gut by bacteria. In vitro, the optimal concentration of inhaled oxygen (about $0.4-0.8 \%$ for SC-positive cells at $40 \% \mathrm{O}_{2}$ and about $0.2-0.7 \%$ for SC-positive cells at $60 \% \mathrm{O}_{2}$ ) induced intestinal mucus to secrete SC, but severe hyperoxia $\left(90 \% \mathrm{O}_{2}\right)$ limited the secretion of SC. However, in vivo, the expression of intestinal SC protein in neonatal rats induced by hyperoxia was increased. The reason for this may be that, in vitro, $90 \% \mathrm{O}_{2}$ acts directly on intestinal epithelial cells, but in vivo, $95 \% \mathrm{O}_{2}$ acts indirectly on the intestine. We speculated that sublethal $\mathrm{O}_{2}$ exposure was associated with induction of antioxidant defense systems

\section{References}

1. Warner BB, Stuart LA, Papes RA, Wispe JR. Functional and pathological effects of prolonged hyperoxia in neonatal mice. Am J Physiol 1998; 275: L110-L117.

2. Smith LE. Pathogenesis of retinopathy of prematurity. Semin Neonatol 2003; 8: 469-473.

3. Madan A, Penn JS. Animal models of oxygen-induced retinopathy. Front Biosci 2003; 8: d1030-d1043.

4. Kaindl AM, Sifringer M, Koppelstaetter A, Genz K, Loeber R, Boerner $\mathrm{C}$, et al. Erythropoietin protects the developing brain from hyperoxia-induced cell death and proteome changes. Ann Neurol 2008; 64: 523-534.

5. Baylor AE, Diebel LN, Liberati DM, Dulchavsky SA, Diglio CA, Brown WJ. The effects of varying oxygen conditions and immunoglobulin A on barrier defense to bacterial invasion. Am Surg 2003; 69: 231-237.

6. Diebel LN, Liberati DM, Brown WJ, Dulchavsky SA, Painter TM, Diglio CA, et al. Secretory immunoglobulin A blocks hypoxia-augmented bacterial passage across Madin-Darby canine kidney cell monolayers. J Trauma 1997; 43: 759763.

7. Diebel LN, Liberati DM, Dulchavsky SA, Diglio CA, Brown WJ. Synergistic effect of hyperoxia and immunoglobulin A on mucosal barrier defense. J Trauma 1999; 46: 374-378.

8. Torbati D, Tan GH, Smith S, Frazier KS, Gelvez J, Fakioglu $\mathrm{H}$, et al. Multiple-organ effect of normobaric hyperoxia in neonatal rats. J Crit Care 2006; 21: 85-93.

9. Giannone PJ, Bauer JA, Schanbacher BL, Reber KM. Effects of hyperoxia on postnatal intestinal development. Biotech Histochem 2007; 82: 17-22.

10. Cunningham-Rundles $C$. Physiology of IgA and IgA deficiency. J Clin Immunol 2001; 21: 303-309.

11. Macpherson AJ, Hunziker L, McCoy K, Lamarre A. IgA responses in the intestinal mucosa against pathogenic and non-pathogenic microorganisms. Microbes Infect 2001; 3: 1021-1035.

12. Boullier S, Tanguy M, Kadaoui KA, Caubet $C$, Sansonetti $\mathrm{P}$, Corthesy B, et al. Secretory IgA-mediated neutralization of Shigella flexneri prevents intestinal tissue destruction by down-regulating inflammatory circuits. J Immunol 2009; 183: and the change in the intestinal environment. The change in intestinal environment may lead to intestinal bacterial disorders (9), which in turn may induce the intestinal epithelial cells to secrete SC.

In vivo and in vitro increases in intestinal SC in response to exposure to moderate hyperoxia would be expected to cause an increase in intestinal SIgA. High levels of SC and SIgA are beneficial to maintaining the optimal state of the intestinal tract.

\section{Acknowledgments}

Research supported by the National Natural Science Foundation of China (\#30871158) and the Education Department Foundation of Liaoning Province (\#2008783).

\section{9-5885}

13. Rey J, Garin N, Spertini F, Corthesy B. Targeting of secretory IgA to Peyer's patch dendritic and T cells after transport by intestinal M cells. J Immunol 2004; 172: 3026-3033.

14. Bomsel M. Transcytosis of infectious human immunodeficiency virus across a tight human epithelial cell line barrier. Nat Med 1997; 3: 42-47.

15. Mazanec MB, Nedrud JG, Kaetzel CS, Lamm ME. A threetiered view of the role of IgA in mucosal defense. Immunol Today 1993; 14: 430-435.

16. Sawai T, Goldstone N, Drongowski RA, Coran AG, Harmon $\mathrm{CM}$. Effect of secretory immunoglobulin A on bacterial translocation in an enterocyte-lymphocyte co-culture model. Pediatr Surg Int 2001; 17: 275-279.

17. Norderhaug IN, Johansen FE, Schjerven H, Brandtzaeg P. Regulation of the formation and external transport of secretory immunoglobulins. Crit Rev Immunol 1999; 19: 481-508.

18. Phalipon A, Corthesy B. Novel functions of the polymeric Ig receptor: well beyond transport of immunoglobulins. Trends Immunol 2003; 24: 55-58.

19. Dallas SD, Rolfe RD. Binding of Clostridium difficile toxin A to human milk secretory component. J Med Microbiol 1998; 47: 879-888.

20. de Araujo AN, Giugliano LG. Lactoferrin and free secretory component of human milk inhibit the adhesion of enteropathogenic Escherichia coli to HeLa cells. BMC Microbiol 2001; 1: 25.

21. Giugliano LG, Ribeiro ST, Vainstein MH, Ulhoa CJ. Free secretory component and lactoferrin of human milk inhibit the adhesion of enterotoxigenic Escherichia coli. J Med Microbiol 1995; 42: 3-9.

22. Hammerschmidt S, Talay SR, Brandtzaeg P, Chhatwal GS. SpsA, a novel pneumococcal surface protein with specific binding to secretory immunoglobulin A and secretory component. Mol Microbiol 1997; 25: 1113-1124.

23. Davids BJ, Palm JE, Housley MP, Smith JR, Andersen YS, Martin MG, et al. Polymeric immunoglobulin receptor in intestinal immune defense against the lumen-dwelling pro- 
tozoan parasite Giardia. J Immunol 2006; 177: 6281-6290.

24. Uren TK, Wijburg OL, Simmons C, Johansen FE, Brandtzaeg $\mathrm{P}$, Strugnell RA. Vaccine-induced protection against gastrointestinal bacterial infections in the absence of secretory antibodies. Eur J Immunol 2005; 35: 180-188.

25. Liu DY, Chen XF, Li JJ. The change of intestinal mucous secretory IgA in neonatal rats by hyperoxia. J China Med Univ 2009; 38: 45-46,49.

26. Yokomizo A, Moriwaki M. Transepithelial permeability of myricitrin and its degradation by simulated digestion in human intestinal Caco-2 cell monolayer. Biosci Biotechnol Biochem 2005; 69: 1774-1776.

27. O'Reilly MA, Marr SH, Yee M, Grath-Morrow SA, Lawrence BP. Neonatal hyperoxia enhances the inflammatory re- sponse in adult mice infected with influenza $\mathrm{A}$ virus. $\mathrm{Am} \mathrm{J}$ Respir Crit Care Med 2008; 177: 1103-1110.

28. Liu DY, Wang XL, Liu P. Tumor necrosis factor-alpha upregulates the expression of immunoglobulin secretory component. J Investig Allergol Clin Immunol 2007; 17: 101-106.

29. Denning GM. IL-4 and IFN-gamma synergistically increase total polymeric IgA receptor levels in human intestinal epithelial cells. Role of protein tyrosine kinases. J Immunol 1996; 156: 4807-4814.

30. Hayashi M, Takenouchi N, Asano M, Kato M, Tsurumachi $\mathrm{T}$, Saito $\mathrm{T}$, et al. The polymeric immunoglobulin receptor (secretory component) in a human intestinal epithelial cell line is up-regulated by interleukin-1. Immunology 1997; 92: 220-225. 